Prepared for the U.S. Department of Energy

under Contract DE-AC05-76RL01830

\title{
American Recovery and Reinvestment Act (ARRA) FEMP Technical Assistance
}

\section{Federal Aviation Administration Project 209 - Control Tower and Support Buillding, Boise, Idaho}

\section{$\mathrm{J}$ Arends \\ WF Sandusky}

June 2010

Pacific Northwest

NATIONAL LABORATORY

Proudly Operated by Battelle Since 1965 


\title{
DISCLAIMER
}

This documentation was prepared as an account of work sponsored by an agency of the United States Government. Neither the United States Government nor any agency thereof, nor Battelle Memorial Institute, nor any of their employees, makes any warranty, express or implied, or assumes any legal liability or responsibility for the accuracy, completeness, or usefulness of any information, apparatus, product, or process disclosed, or represents that its use would not infringe privately owned rights. Reference herein to any specific commercial product, process, or service by trade name, trademark, manufacturer, or otherwise does not necessarily constitute or imply its endorsement, recommendation, or favoring by the United States Government or any agency thereof, or Battelle Memorial Institute. The views and opinions of authors expressed herein do not necessarily state or reflect those of the United States Government or any agency thereof.

\author{
PACIFIC NORTHWEST NATIONAL LABORATORY \\ operated by \\ BATTELLE \\ for the \\ UNITED STATES DEPARTMENT OF ENERGY \\ under Contract DE-AC05-76RL01830
}

Printed in the United States of America

Available to DOE and DOE contractors from the Office of Scientific and Technical Information,

P.O. Box 62, Oak Ridge, TN 37831-0062;

ph: (865) 576-8401, fax: (865) 576-5728

email: reports@adonis.osti.gov

Available to the public from the National Technical Information Service,

U.S. Department of Commerce, 5285 Port Royal Rd., Springfield, VA 22161

ph: (800) 553-6847, fax: (703) 605-6900

email: orders@ntis.fedworld.gov

online ordering: http://www.ntis.gov/ordering.htm

This document was printed on recycled paper.

$(8 / 00)$ 


\title{
American Recovery and Reinvestment Act (ARRA) FEMP Technical Assistance \\ Federal Aviation Administration - Project 209 \\ Control Tower and Support Building \\ Boise, Idaho
}

\author{
J Arends $\left({ }^{a}\right)$ \\ WF Sandusky
}

June 2010

Prepared for

U.S. Department of Energy

Federal Energy Management Program

under Contract DE-AC05-76RL01830

Pacific Northwest National Laboratory

Richland, Washington 99352

(a) Redhorse Corporation 


\section{Executive Summary}

Pacific Northwest National Laboratory (PNNL) and Redhorse Corporation (Redhorse) conducted an energy audit on the Federal Aviation Administration (FAA) control tower and base building in Boise, Idaho. This report presents findings of the energy audit team that evaluated construction documents and operating specifications (at the $100 \%$ level) followed by a site visit of the facility under construction. The focus of the review was to identify measures that could be incorporated into the final design and operating specifications that would result in additional energy savings for FAA that would not have otherwise occurred.

The process that was followed in this review was to first identify various energy conservation measures (ECMs) that should be considered before the construction is complete in the October 2010. A total of seven recommendations were evaluated and documented in this report. During the debriefing, FAA representatives indicated all were likely to be incorporated into the final construction project. Contingency funds from construction of the facility will be used to implement the recommendations. These recommendations included both low-cost and no-cost projects that typically related to operational requirements, as well as capital projects that would result in an actual design change. Implementation of the seven measures would result in an electrical energy savings of 148,766 kilowatt hours ( $\mathrm{kWh}$ ). No savings related to natural gas were identified because the facility does not use natural gas. Based on the present commodity rates, the annual cost savings for the site would be $\$ 5,977$. The total cost for implementation is estimated to be $\$ 27,754$, resulting in a simple payback of 4.6 years.

A total of two renewable energy projects were identified - one related to solar domestic hot water and the other solar power electric generation. If these projects were implemented, an additional 191,482 kWh would be saved, resulting in an annual cost savings of $\$ 7,057$. The cost for implementation is estimated to be $\$ 1,401,192$, which is not cost-effective unless incentive funds can be secured.

Project implementation would reduce greenhouse gas (GHG) emissions to the atmosphere and create jobs for local workers. It is estimated that 104 metric tons of carbon dioxide equivalent $\left(\mathrm{CO}_{2} \mathrm{e}\right)$ emissions would be avoided by implementation of the seven ECMs, and 0.3 new jobs would be created (based on the premise that $\$ 92,000$ in project costs equals one new job). With implementation of the renewable energy projects that were evaluated, an estimated 134 metric tons of $\mathrm{CO}_{2} \mathrm{e}$ emissions would be avoided, and 15.2 new jobs would be created for the installation of solar renewable energy systems. 


\section{Contents}

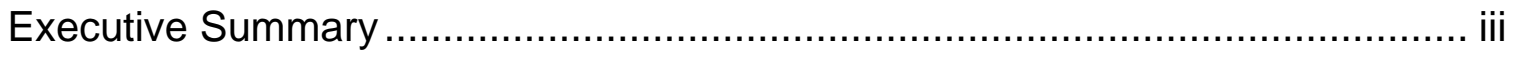

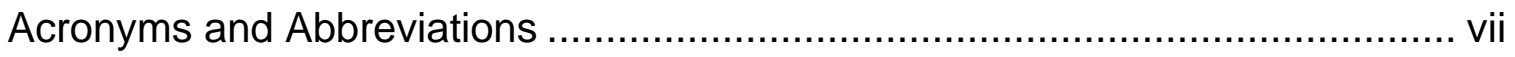

1.0 Description of ARRA Program ................................................ 1

1.1 Technical Assistance Activities .................................................... 2

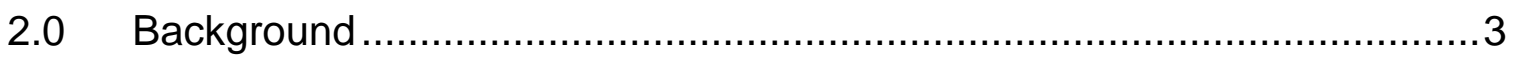

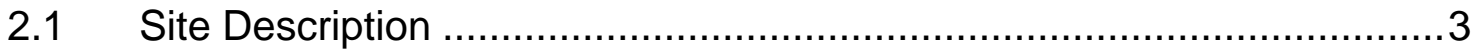

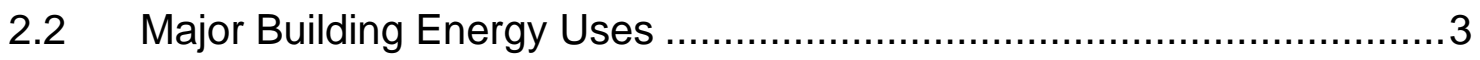

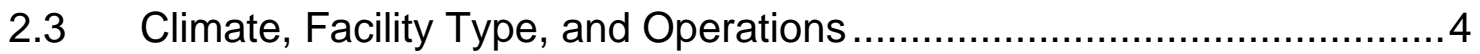

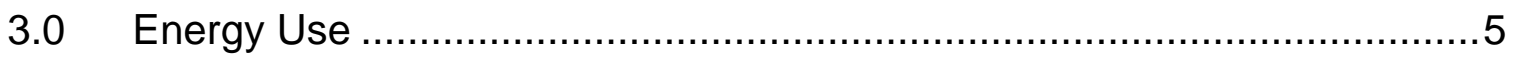

3.1 Current Energy, Gas, and Water Use ..................................... 5

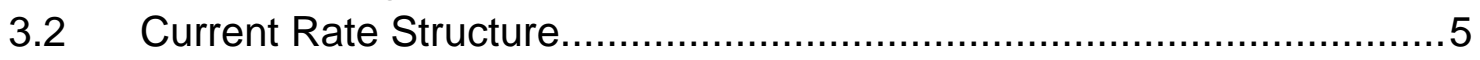

4.0 Energy Conservation Measures Identified ...................................... 7

4.1 Summary of Proposed Measures ........................................... 8

4.2 Renewable Energy Measures Evaluated..................................... 12

5.0 Potential Green House Gas Reduction ........................................ 13

6.0 Action Plan for Implementation of ECMs ..................................... 15

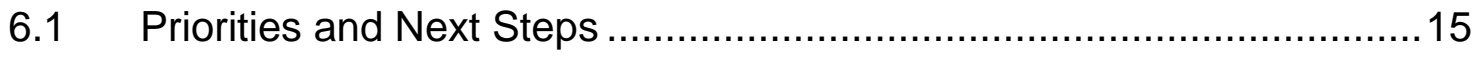

$6.2 \quad$ Funding Assistance Available .............................................. 15

7.0 Assessment Team Members and Site Team .................................17

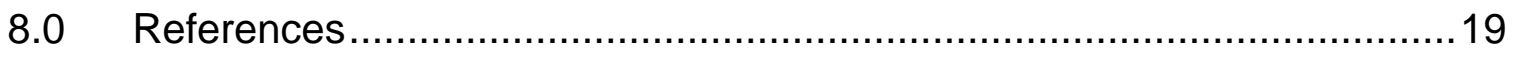

Appendix A: eQUEST Modeling Results and Spreadsheet Calculations .......... A-1

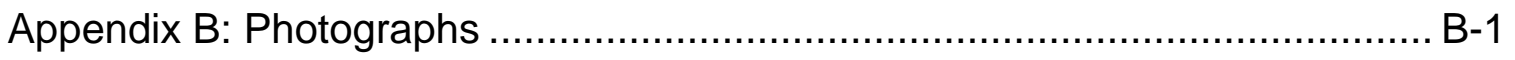




\section{Figures}

Figure 1. The Boise Airport Control Tower and Base Building (computer simulation)

\section{Tables}

Table 1: ECMs Recommended for Incorporation in the Final Construction Specifications

Table 2: Estimated Greenhouse Gas Reductions 


\section{Acronyms and Abbreviations}

\begin{tabular}{|c|c|}
\hline$A C$ & air conditioning \\
\hline AHU & air handling unit \\
\hline ALERT & Assessment of Load and Energy Reduction Techniques \\
\hline ARRA & American Recovery and Reinvestment Act \\
\hline ASHRAE & $\begin{array}{l}\text { American Society of Heating, Refrigerating \& Air Conditioning } \\
\text { Engineers }\end{array}$ \\
\hline BAS & building automation system \\
\hline BCS & building control system \\
\hline BLCC & building life cycle cost \\
\hline Btu & British thermal unit \\
\hline CF & cubic feet $\left(\mathrm{ft}^{3}\right)$ \\
\hline $\mathrm{CO}_{2} \mathrm{e}$ & carbon dioxide equivalent \\
\hline CRAC & computer room air conditioning \\
\hline DC & direct current \\
\hline DCV & demand controlled ventilation \\
\hline DDC & direct digital control \\
\hline DOE & U.S. Department of Energy \\
\hline DX & direct expansion \\
\hline E4 & energy efficiency expert evaluations \\
\hline ECM & energy conservation measure \\
\hline EISA & Energy Independence and Security Act \\
\hline EPAct & Energy Policy Act \\
\hline ESET & energy savings expert teams \\
\hline ESPC & energy savings performance contract \\
\hline EUI & energy use intensity \\
\hline $\begin{array}{l}\text { FAA } \\
\mathrm{ft}^{2}\end{array}$ & $\begin{array}{l}\text { Federal Aviation Administration } \\
\text { square feet }\end{array}$ \\
\hline FEMP & Federal Energy Management Program \\
\hline GHG & greenhouse gas \\
\hline GSA & General Services Administration \\
\hline IAQ & indoor air quality \\
\hline IR & infrared \\
\hline kBtu & $10^{3} \mathrm{Btu}$ \\
\hline
\end{tabular}




$\begin{array}{ll}\text { kW } & \text { kilowatt } \\ \text { kWh } & \text { kilowatt hour (1 kWh = 3412 Btu) } \\ \text { lb/hr } & \begin{array}{l}\text { pounds per hour } \\ \text { LBNL }\end{array} \\ \text { Lawrence Berkeley National Laboratory } \\ \text { Mcf } & \text { million cubic feet (natural gas) } \\ \text { mm } & \text { millimeter } \\ \text { MMBtu } & 10^{6} \text { Btu } \\ \text { NOFA } & \text { notice of funding available } \\ \text { O\&M } & \text { operation and maintenance } \\ \text { PM } & \text { preventive maintenance } \\ \text { ppm } & \text { parts per million } \\ \text { PNNL } & \text { Pacific Northwest National Laboratory } \\ \text { PV } & \text { photovoltaic } \\ \text { Retro-CX } & \text { retro-commissioning } \\ \text { SHW } & \text { solar domestic hot water } \\ \text { SPV } & \text { solar photovoltaic } \\ \text { VAV } & \text { variable air volume } \\ \text { Yr } & \text { year }\end{array}$




\subsection{Description of ARRA Program}

The Federal Energy Management Program (FEMP) facilitates the Federal government's implementation of sound, cost-effective energy management and investment practices to enhance the nation's energy security and environmental stewardship. In fiscal year 2009, FEMP received funds specific to the American Recovery and Reinvestment Act (ARRA) to assist in the identification, evaluation, and documentation of energy efficiency and renewable energy projects at Federal sites.

These funds were allocated to extend laboratory and contractor support to agencies and to quickly provide technical advice and assistance to expand and accelerate project activities. FEMP requested that agencies submit projects requesting technical assistance in the following areas:

- Initial screenings or assessments of facility needs or feasibility of a particular technology

- Project prioritization

- Strategic energy planning and benchmarking

- Technical reviews of designs and proposals

- Energy audit training

- High-performance green building technical support

- Federal vehicle fleet technical support

- Operations and maintenance (O\&M)

- Detail of key laboratory staff to work within agencies for a limited duration (normally not more than 24 months)

- All of the above, with special emphasis on particular technologies in the areas of the laboratory's expertise.

The Federal Aviation Administration (FAA) submitted a response to a FEMP call for projects that was issued on May 1, 2009, requesting that energy audits be conducted at four FAA locations in California, with the goal of identifying energy conservation measures (ECMs) that could be implemented in a timely manner. This project was accepted by FEMP and designated as Project 209. After project selection, it was determined that the sites were being considered as part of a larger energy savings performance contract (ESPC) project, so the scope of the project was changed and divided into two parts. The first part consisted of a technical review of the proposed construction and operating specifications for buildings to be constructed at three airport locations (Las Vegas, Nevada, and Palm Springs and Oakland, California). The second part was a request for 
energy audits during on-going construction at two other sites (Reno, Nevada, and Boise, Idaho). This report presents the findings of the energy audit at the Boise site. The results of the other reviews and audits are documented in separate reports.

\subsection{Technical Assistance Activities}

This energy and water audit was conducted using the protocols and guidance developed by PNNL to support previous FEMP activities related to assessment of load and energy reduction techniques (ALERT), energy savings expert teams (ESET), and energy efficiency expert evaluation (E4) audits at Federal sites. The primary focus of the protocols is to identify various no-cost and low-cost opportunities for major energy consuming equipment within the building. During the audit, however, other capital cost equipment opportunities were also considered with respect to future energy efficiency projects that could be undertaken by the sites to achieve additional energy, water, and cost savings.

PNNL contracted with Redhorse to complete a review of construction design and operation specifications and complete a site visit to the buildings in Boise. The purpose was to identify additional ECMs or operating specifications that could be provided to FAA for consideration to meet final construction completion timelines. Redhorse developed estimates of potential energy savings impacts for those design review comments that could be incorporated in the final construction documents.

The design team used the Carrier Hourly Analysis Program (HAP) energy modeling program to model the energy use of the systems selected for the building. Recommended measures were evaluated for potential energy savings using the eQUEST model.

The eQUEST model was developed to provide a quick estimate of the energy savings potential and does not include the fine degree of detail included in the Carrier HAP model. The inputs of the eQUEST model were adjusted until annual energy use estimates from the model matched the design team's results. The eQUEST model was developed using the schematic wizard function to develop a simple model of the building and its systems. However, some of the items were estimated using case studies, and energy estimates were extrapolated for this project. 


\subsection{Background}

\subsection{Site Description}

On January 4, 2008, officials broke ground for Boise Air Terminal's latest improvement, a new air traffic control tower to be located at $3001 \mathrm{~W}$. Harvard Street. When completed in late 2010, the new tower will stand 290 feet tall, becoming Idaho's tallest structure and the Pacific Northwest's tallest control tower. The new control tower will provide 525 square feet $\left(\mathrm{ft}^{2}\right)$ of space with a full view of the airfield. In addition to the new control tower, a new single-story base support building is under construction with $11,000 \mathrm{ft}^{2}$ of office, data center, and support space. The construction site for the buildings is located on the south side of the airport to control an existing Idaho Air National Guard assault strip and a possible new runway south of Gowen Field. Figure 1 is a computer simulation of the proposed control tower and base building.

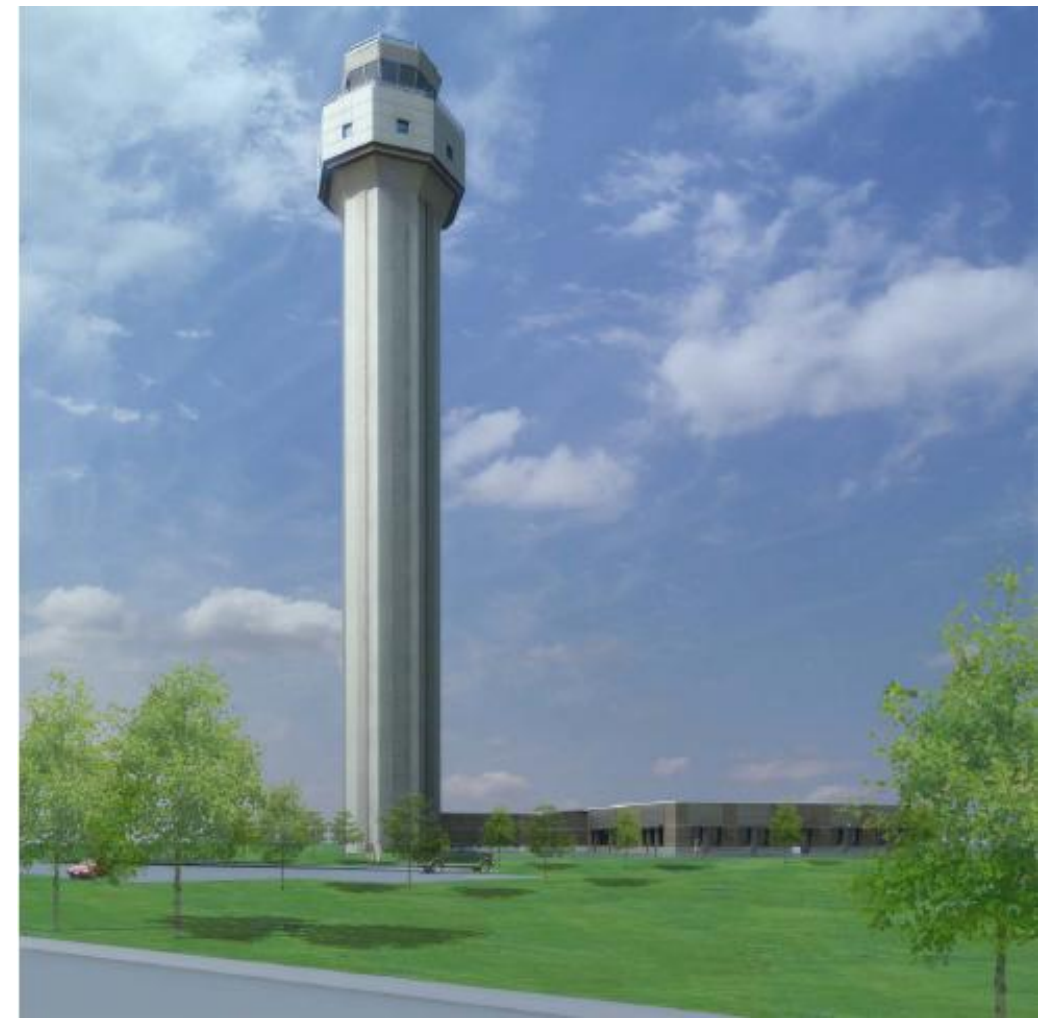

Figure 1. The Boise Airport Control Tower and Base Building (computer simulation)

\subsection{Major Building Energy Uses}

The major end uses of energy at the buildings will be lighting, space cooling, ventilation, and equipment (radar and communication). Minor end uses will be space heating, water heating, and pumps and motors. 
The base building and control tower are served by two packaged air-cooled chilled water chillers with variable speed pumping, which are located on a concrete pad outside the buildings. The central station variable volume air handling unit (AHU) is located in a mechanical room in the base building. Air supplied by the central station AHU is distributed throughout the base building to variable air volume (VAV) terminal units with electric reheat elements. The base building data and equipment rooms are served by three chilled water computer room air conditioning (CRAC) units.

The control tower is served by a two-pipe fan coil system with chilled water coils and electric heating elements.

\subsection{Climate, Facility Type, and Operations}

The climate for the site is considered semi-arid and continental, with four distinct seasons. Based on data available from the National Climatic Data Center, the maximum mean monthly temperature occurs in July $\left(74.7^{\circ} \mathrm{F}\right)$, with the minimum mean monthly temperature occurring in January $\left(30.2^{\circ} \mathrm{F}\right)$. The highest recorded temperature during the period from 1940 through 2001 was $111^{\circ} \mathrm{F}$, while the lowest reported temperature during that period was $-25^{\circ} \mathrm{F}$. Based on the most recent mean data available (1971-2000), the site should experience 46 days with a maximum temperature exceeding or equal to $90^{\circ} \mathrm{F}$ and 6 days with a maximum temperature exceeding or equal to $100^{\circ} \mathrm{F}$. The minimum temperature should be at or below $32^{\circ} \mathrm{F}$ for 118 days. Annually, the site should anticipate 5,727 heating degree days (HDD) and 807 cooling degree days (CDD).

Mean annual precipitation for the site is 12.19 inches. The highest daily reported precipitation was 1.91 inches on June 12, 1958. The highest reported monthly precipitation, 4.4 inches, occurred in May 1998. The daily precipitation should be at or greater than 0.01 inch for 90 days during the year. Mean annual snowfall for the site is 19.4 inches, and the highest monthly snowfall was reported in December 1983 (26.2 inches). The highest daily snow depth was 13+ inches on December 2, 1985. 


\subsection{Energy Use}

Historical energy use data for the buildings are not presented because the buildings are under construction.

\subsection{Current Energy, Gas, and Water Use}

Specific information regarding energy, natural gas, and water use was not obtained because the building is under construction. Information from the existing facility would not be appropriate for use in this report.

\subsection{Current Rate Structure}

The FAA currently pays 3.5 cents per kilowatt hour (kWh) to Idaho Power. No natural gas is used at this site. This value was used in calculating the baseline energy consumption and the incremental savings from the various proposed measures. United Water Idaho provides water service to the site. 


\subsection{Energy Conservation Measures Identified}

The energy audit team identified a total of seven ECMs that should be considered by the FAA building design team. These ECMs represent a variety of measures and operating specifications for equipment, and include both nocost/low-cost projects, as well as additional capital investment projects. These ECMs were evaluated in reference to annual energy and cost savings, using a simple payback method. A detailed savings summary is included in Table 1 below. Energy savings estimates are based on individual results and do not represent the interactive effect they have on each other. Savings in Table 1 are estimated reductions in energy use compared with the baseline or existing building energy usage model. A summary of those measures, estimated electrical savings, associated electric annual cost savings, along with implementation cost and the simple payback calculation, is provided in Table 1.

Several renewable energy projects were also identified for the building, including installation of a solar domestic hot water (SHW) system and solar photovoltaic (PV) generation. The evaluation did not include the impact of obtaining rebates or incentives.

Table 1: ECMs Recommended for Incorporation in the Final Construction Specifications

\begin{tabular}{|c|c|c|c|c|c|c|c|c|c|c|c|}
\hline $\begin{array}{c}\mathrm{ECM} \\
\#\end{array}$ & $\begin{array}{c}\text { Energy Saving } \\
\text { Recommendations }\end{array}$ & $\begin{array}{c}\text { Electrical } \\
\text { Savings } \\
\text { (kWh) }\end{array}$ & $\begin{array}{c}\text { Natural } \\
\text { Gas } \\
\text { Savings } \\
\text { (Therms) }\end{array}$ & $\begin{array}{l}\text { Energy } \\
\text { Savings } \\
\text { (Millions } \\
\text { of Btus) }\end{array}$ & $\begin{array}{c}\text { Water } \\
\text { Savings } \\
\text { (Gallons) }\end{array}$ & $\begin{array}{l}\text { Electrical } \\
\text { Savings } \\
\text { (\$) }\end{array}$ & $\begin{array}{l}\text { Natural } \\
\text { Gas } \\
\text { Savings } \\
\text { (\$) }\end{array}$ & $\begin{array}{l}\text { Water } \\
\text { Savings } \\
\text { (\$) }\end{array}$ & $\begin{array}{c}\text { Total } \\
\text { Annual } \\
\text { Savings } \\
\text { (\$) }\end{array}$ & $\begin{array}{l}\text { Cost to } \\
\text { Implement } \\
\text { (\$) }\end{array}$ & $\begin{array}{c}\text { Simple } \\
\text { Payback } \\
\text { (Years) }\end{array}$ \\
\hline 1 & Static Pressure Reset & 12,530 & 0 & 43 & & $\$ \quad 439$ & $\$$ & $\$$ & $\$ \quad 439$ & $\$ \quad 1,200$ & 2.7 \\
\hline 2 & DCV CO2 sensors & 5,140 & 0 & 18 & & 180 & $\$$ & $\$$ & 180 & 1,000 & 5.6 \\
\hline 3 & $\begin{array}{l}\text { Lighting \& HVAC Occupancy } \\
\text { Sensors }\end{array}$ & 73,550 & 0 & 251 & & $\$ \quad 2,574$ & $\$$ & $\$$ & 2,574 & 4,150 & 1.6 \\
\hline 4 & Ultrasonic Humidifiers & 53,046 & 0 & 181 & & $\$ \quad 1,857$ & $\$$ & $\$$ & 1,857 & 14,000 & 7.5 \\
\hline 5 & $\begin{array}{l}\text { No Touch Sink Faucets } 6 \text { ea (1.0 } \\
\text { vr } 0.25 \mathrm{gpc})\end{array}$ & 4,500 & 0 & 15 & 79,560 & 158 & $\$$ & 636 & 794 & 1,980 & 2.5 \\
\hline 6 & $\begin{array}{l}\text { No Touch Urinals } 2 \text { ea (1.0 vr } 0.5 \\
\text { gpf) }\end{array}$ & 0 & 0 & 0 & 10,950 & $\$$ & $\$$ & 88 & 88 & 1,356 & 15.5 \\
\hline 7 & $\begin{array}{l}\text { No Touch Toilets } 6 \text { ea (1.6 vs } 1.28 \\
\text { gpf) }\end{array}$ & 0 & 0 & 0 & 5,824 & $\$$ & $\$$ & 47 & 47 & 4,068 & 87.3 \\
\hline & Total (Non-interactive) & 148,766 & 0 & 508 & 96,334 & $\$ 5,207$ & $\$$ & 771 & 5,977 & 27,754 & 4.6 \\
\hline & $\begin{array}{l}\text { Percent Savings (Non- } \\
\text { interactive) }\end{array}$ & $20 \%$ & & $20 \%$ & & & & & & & \\
\hline & & & & & & & & & & & \\
\hline & Renewable Energy & & & & & & & & & & \\
\hline 8 & Solar Domestic Hot Water & 410 & 0 & 1 & & $\$ \quad 369$ & $\$$ & & 369 & 1,192 & 3.2 \\
\hline 9 & Solar Power Generation -140 kW & 191,072 & & 652 & & $\$ 6,688$ & $\$$ & & 6,688 & $\$ 1,400,000$ & 209.3 \\
\hline & Total Renewable Energy & 191,482 & 0 & 654 & & $\$ 7,057$ & $\$$ & & $\$ 7,057$ & $\$ 1,401,192$ & 198.6 \\
\hline \multicolumn{12}{|c|}{2009 Reference Data } \\
\hline & & $\begin{array}{c}\text { Annual } \\
\text { Electrical } \\
\text { Use } \\
\text { (kWh) }\end{array}$ & $\begin{array}{l}\text { Annual } \\
\text { Natural } \\
\text { Gas Use } \\
\text { (Therms) }\end{array}$ & $\begin{array}{c}\text { Annual } \\
\text { Energy } \\
\text { Use } \\
\text { (Millions } \\
\text { of Btus) }\end{array}$ & $\begin{array}{c}\text { Annual } \\
\text { Water } \\
\text { Use } \\
\text { (Gallons) }\end{array}$ & $\begin{array}{l}\text { Electrical } \\
\text { Cost }\end{array}$ & $\begin{array}{c}\text { Natural } \\
\text { Gas Cost }\end{array}$ & $\begin{array}{l}\text { Water } \\
\text { Cost }\end{array}$ & $\begin{array}{c}\text { Total } \\
\text { Annual } \\
\text { Utility Use } \\
\text { (\$) }\end{array}$ & $\begin{array}{c}\text { Total Annual } \\
\text { Energy Use } \\
\text { (\$) }\end{array}$ & \\
\hline & Cost Per Unit 2009 & & & & & 0.0350 & 0.9000 & 0.00800 & & & \\
\hline & eQUEST Baseline 2009 & 759,120 & 0 & 2,591 & 182,719 & $\$ 26,569$ & $\$$ & $\$ \quad 21$ & $\mathrm{NA}$ & 26,569 & \\
\hline & eQUEST I Actual Use Ratio & $100.0 \%$ & & $100.0 \%$ & \multicolumn{7}{|c|}{ Modeling estimates should fall within $5 \%$ of actual usage. } \\
\hline & Design Baseline Estimate & 759,000 & & 2,590 & & $\$ 26,565$ & $\$$ & $\$$ & $\$ 26,565$ & 26,565 & \\
\hline & $\begin{array}{c}\text { Actual Energy Use Intensity (EUI) } \\
-(\text { (BTU/SF-YR) }\end{array}$ & 122,870 & 0 & 122,870 & & & & & & & \\
\hline
\end{tabular}




\subsection{Summary of Proposed Measures}

\section{ECM1 - VARIABLE AIR VOLUME (VAV) STATIC PRESSURE RESET:}

Air static pressure in a VAV air handling system is normally maintained by modulating the speed of the fan. Air is distributed throughout the building by ductwork, and VAV terminal boxes control the flow of cool air delivered to the space they serve. As the space cooling load increases, the flow of cold air likewise increases to maintain the space temperature. If space cooling loads decrease, the requirement for cold air flow to cool the space also decreases.

The air flow to the VAV terminal boxes is delivered at a system static pressure. The static pressure level is established by the minimum pressure required for the terminal boxes to deliver full cooling flows. During the winter, air flow requirements drop to their minimum levels and the static pressure required at terminal boxes decreases. This reduced air flow requirement brings about an opportunity to reduce the system static pressure levels along with reducing energy usage. Static pressure reset control strategies have been in use for more than 20 years and have been proven to provide significant levels of energy savings.

An eQUEST energy model was developed and the estimated annual energy savings are summarized in Table 1. The energy efficiency measure wizard option to model static pressure reset is not included in the current version of eQUEST. The magnitude of energy savings was estimated by modeling the baseline VAV system as a forward curved fan system with inlet vane dampers, and the static pressure reset option was modeled as a standard VAV system with variable speed drives.

Implementation of the improved air static pressure reset control can greatly increase the energy savings. Since 1999, American Society of Heating, Refrigerating and Air-Conditioning Engineers (ASHRAE) Standard 90.1 has required that static air pressure be reset for systems with direct digital controls (DDC): "the setpoint is reset lower until one zone damper is nearly wide open." However, system design deficiencies often limit the potential energy savings. These design deficiencies create problem zones that cause the reset scheme to underperform because they frequently or constantly generate zone pressure increase requests.

Common causes are:

- Undersized VAV box because of improper selection in the design phase or unexpectedly high zone loads that are added to the space after construction;

- Cooling thermostat setpoint below design condition;

- Thermostats with heat releasing equipment under them (such as microwaves and coffee pots); and 
- Air distribution design problems-high-pressure drop fittings or duct sections.

The first three items cause the zone to frequently demand maximum or nearmaximum zone air flow rates. Depending on zone location relative to the fan, a constant demand for high air flow rates indirectly causes the zone to generate frequent or constant pressure requests. The fourth problem directly results in pressure requests. For example: A zone with a fire/smoke damper installed in the 6-inch (150 millimeter [mm]) high-pressure duct at the box inlet. Small smoke dampers have little free area so pressure drop will be high.

Ways to mitigate the impact of problem zones on static pressure reset control sequences include:

- Exclude the problem zones from the reset control sequence by literally ignoring the problem zone's pressure requests or including logic that ignores the first few pressure requests. Of course, ignoring the zone results in failure to meet zone air flow and temperature setpoints. This failure may be acceptable if the zone is a problem because the temperature setpoint is too low, but it clearly can be an issue if the zone is more critical.

- Limit thermostat setpoint adjustments to a range that is close to space design temperatures. Direct digital control (DDC) systems typically have the ability to limit the range occupants can adjust setpoints from the thermostat. This limitation can prevent, for instance, cooling setpoints that are well below design conditions.

- Request that all thermostats are free of impact from appliances directly under them.

- Fix duct restrictions/sizing issues. This option is clearly a better choice than ignoring the zone and letting it overheat, but the cost to make revisions may be higher that the owner is willing to invest. It is best, of course, to avoid these restrictions in the first place. For instance, the owner should avoid using flexible duct at VAV box inlets, avoid oversized inlet ducts when they extend a long way from the duct main, and avoid small fire/smoke dampers in VAV box inlet ducts.

- Add auxiliary cooling to augment the VAV zone. If the problem results from an undersized zone or unexpectedly high loads, a second cooling system, such as a split air conditioning (AC) system, can be added to supplement the VAV zone capacity. However, this solution is also expensive.

ECM2 - DEMAND-CONTROLLED VENTILATION (DCV) USING CARBON DIOXIDE $\left(\mathrm{CO}_{2}\right)$ SENSING:

ASHRAE recommends a ventilation rate of 15 to 20 cubic feet per minute (cfm) per person in ASHRAE Standard 62-1999 to ensure adequate air quality in buildings. To meet the standard, many ventilation systems are designed to admit 
air at the maximum level whenever a building is occupied, as if every area were always at full occupancy. The result, in many cases, has been buildings that are highly over-ventilated. The development of $\mathrm{CO}_{2}$-based $\mathrm{DCV}$ was driven in part by the need to satisfy ASHRAE 62 without over-ventilating.

When $\mathrm{CO}_{2}$ sensors are used to maintain indoor air quality (IAQ), they continuously monitor the air in a conditioned space. Because people constantly exhale $\mathrm{CO}_{2}$, the difference between the indoor $\mathrm{CO}_{2}$ concentration and the outdoor concentration indicates the occupancy or activity level in a space and thus its ventilation requirements. An indoor/outdoor $\mathrm{CO}_{2}$ differential of 700 parts per million (ppm) is usually assumed to indicate a ventilation rate of 15 $\mathrm{cfm} /$ person; a differential of $500 \mathrm{ppm}$ indicates a $20 \mathrm{cfm} /$ person ventilation rate. The $\mathrm{CO}_{2}$ sensor readings are monitored at the air handling system control panel, which automatically increases ventilation when the $\mathrm{CO}_{2}$ concentration in a zone rises above a specified level.

The highest payback can be expected in high-density spaces where occupancy is variable and unpredictable (such as auditoriums, some school buildings, meeting areas, and retail establishments), in locations with high heating or cooling demand (or both), and in areas with high utility rates. Case studies show DCV offers greater savings for heating than for cooling. In areas where peak power demand and peak prices are an issue, DCV can be used to control loads in response to real-time prices. DCV may result in significant cost savings even with little or no energy savings in those locations. Energy savings can be as high as $10 \%$. The potential energy cost savings for $\mathrm{CO}_{2}$-based DCV is estimated to range from $\$ 0.05$ to more than $\$ 1$ per $\mathrm{ft}^{2}$ annually.

The reliability of $\mathrm{CO}_{2}$ sensors has improved in recent years, and they should be considered for use in the modern energy efficient office.

Estimated annual energy savings are summarized in Table 1. The conference room VAV box and AHU-1 are recommended systems to be controlled by $\mathrm{CO}_{2}$ sensors.

\section{ECM3 - OCCUPANCY SENSOR CONTROLLED HEATING, VENTILATION, AND AIR CONDITIONING (HVAC):}

Lighting occupancy sensors can be used to reduce the HVAC heating and cooling energy use in spaces that are not occupied. Temperatures in the unoccupied space are allowed to drift from occupied setpoints while the space is unoccupied. The state of the occupancy sensor is tapped by the building energy management system to control the heating or cooling setpoint of the space.

Office buildings with occupancy sensors controlling the lighting typically see electricity savings of between 38 to $48 \%$. When the heating and cooling setpoints of the room are also controlled by the occupancy sensor, the HVAC savings will be less than the lighting energy savings because the ventilation system continues to provide minimum ventilation during the unoccupied periods. An example is an office that is unoccupied during a 2-week period while the 
occupant is on vacation. If this office is unoccupied during the winter, the office still needs to be kept above some minimum temperature (typically no less than $55^{\circ} \mathrm{F}$ ). In one case study, almost $42 \%$ of the lighting and $23 \%$ of the cooling energy were saved in the private executive office, with potential for even higher savings in applications such as conference rooms and lunch rooms.

Energy savings estimates are included in Table 1 . The recommended VAV terminal boxes for installation of occupancy sensors are VAVs 1, 2, 3, 6, 9, 10, 11 and 14; break room VAV 7 and the conference room VAV box.

\section{ECM4 - ULTRASONIC HUMIDIFIERS:}

The humidifiers installed during construction are electric resistance humidifiers, and this measure recommends their replacement with ultrasonic humidifiers. Ultrasonic humidifiers use a piezo-electric transducer to create a high-frequency mechanical oscillation in a body of water. The water tries to follow the highfrequency oscillation but cannot because of its comparative weight and mass inertia. Thus, a momentary vacuum is created on the negative oscillation, causing the water to cavitate into vapor. The transducer follows with a positive oscillation that creates high pressure compression waves on the water's surface, releasing tiny droplets of water into the air. This mist is extremely fine, with droplets about 1 micron in diameter, which are quickly absorbed into the air flow. Because the mist is created by oscillation, and not heat, the water temperature need not be raised. Ultrasonic humidifiers, therefore, can create instantaneous humidity, and don't have to wait for a heating element to vaporize the water. This precise on/off humidity control is the hallmark of ultrasonic humidifiers. In addition, unlike wet pad humidifiers, ultrasonic units can be of comparatively small size while still providing sufficient humidity.

Ultrasonic humidifiers generate 1-micron size droplets for as little as 1/13 the price of steam and can save thousands of dollars in annual operating costs. Ultrasonic humidifiers are proven to reduce humidifier energy use by between 90 and $93 \%$.

Maintenance: Because water is purified before entry into the ultrasonic humidifier, there is considerably less maintenance required of an ultrasonic system compared to steam.

Ultrasonic systems provide instant on/off of mist. As soon as the relative humidity drops below the setpoint, an ultrasonic humidifier instantly turns on. Steam canisters have flush cycles that may shut down the humidifier for up to 15 minutes or more. Heating elements inside those systems take significant time to vaporize water to create humidity.

Equipment costs for ultrasonic humidifiers are typically higher than equipment costs for other types of humidifiers, while installation costs are typically lower. A 100 pound per hour (Ib/hr) ultrasonic humidifier costs approximately $\$ 13,400$, with an installation cost of $\$ 1,000$, or approximately $\$ 145$ per pound of capacity. A similar sized steam canister humidifier would cost $\$ 3,400$ with a $\$ 2,000$ 
installation cost. Two documented retrofit applications averaged \$205 and \$269 per pound of capacity, including installation (DOE 1998). In those two instances, however, the total retrofit costs were similar to the estimated costs using electric resistance humidifiers.

Energy savings estimates are included in Table 1. The estimate provided is based on capturing $90 \%$ of the operational cost of the existing electric steam unit.

ECM5, 6 \& 7 - NO TOUCH SINKS, TOILETS, AND URINALS:

No touch solar (instead of battery) operated sink faucets have 0.25 gallon per cycle operation, and they also promote sanitary cleanliness in the bathroom. No touch toilets and urinals are always flushed, odor-free, and presentable. An infrared sensor and solenoid valves activate water flow and eliminate crosscontamination from touching fixture handles. This also helps to control the spread of infectious diseases. A 1.28 gallon per flush version for the toilet and a 0.5 gallon per flush version of the urinal flush valve are the recommended options to replace the existing 1.6 gallon per flush toilet valves and 1.0 gallon per flush urinal valves.

Automatic operation provides water usage savings over other manual devices and reduces O\&M costs. Water savings estimates are included in Table 1.

\subsection{Renewable Energy Measures Evaluated}

Two renewable energy measures were initially recommended, and FAA is in the process of identifying funding for implementation.

ECM9 - Solar Heating of DOMEstic Hot WATER:

Solar hot water heating systems are typically mounted on the roof of the building they serve. The roof of the base building is available for the installation of a solar hot water collector. The collector was sized for 20 people in the building. A collector laying flat on the building roof would cover an area of approximately 15

$\mathrm{ft}^{2}$. One collector unit would provide $60 \%$ of the domestic hot water heating needed for the building.

ECM10 - Solar Power Generation - 140 Kilowatts (KW):

Solar power generation is feasible at the site because large areas of open ground space are available. The west side of the site has the largest open area, with a space that is 300 by 500 feet or $150,000 \mathrm{ft}^{2}$. A $140-\mathrm{kW}$ system array will require about $14,000 \mathrm{ft}^{2}$. This output capacity is suggested because it would provide an output slightly less than the projected typical demand of the facility. The alternative location for the solar array would be the roof of the base building, but the size of the system would be limited to approximately $100 \mathrm{~kW}$. 


\subsection{Potential Green House Gas Reduction}

The potential greenhouse gas emission reductions resulting from the ECMs were calculated based on the U.S. Environmental Protection Agency eGRID data (Pechan 2008), and are tabulated in Table 2. Based on the estimated savings of $148,766 \mathrm{kWh}$, annual non-baseload carbon dioxide equivalent $\left(\mathrm{CO}_{2} \mathrm{e}\right)$ emissions would be reduced by 104 metric tons. Implementing the renewable energy projects would result in an additional estimated reduction of 134 metric tons of $\mathrm{CO}_{2} \mathrm{e}$ from a renewable energy savings of $191,482 \mathrm{kWh}$. These calculations do not include any contribution that would be related to line losses.

Table 2: Estimated Greenhouse Gas Reductions

\begin{tabular}{|c|c|c|c|c|c|}
\hline ECM \# & $\begin{array}{l}\text { Estimated } \\
\text { Electrical } \\
\text { Savings } \\
\text { (kWh) } \\
\end{array}$ & $\begin{array}{l}\text { Natural } \\
\text { Gas } \\
\text { Savings } \\
\text { (Therms) }\end{array}$ & $\begin{array}{l}\text { (Est. Electrical } \\
\text { Use Reduction) } \\
\text { (metric tons } \\
\text { CO2e) }\end{array}$ & $\begin{array}{l}\text { GHG Avoided (Est. } \\
\text { Natural Gas Use } \\
\text { Reduction) (metric } \\
\text { tons CO2e) }\end{array}$ & $\begin{array}{l}\text { Total GHG } \\
\text { Avoided } \\
\text { (metric tons } \\
\text { CO2e) } \\
\end{array}$ \\
\hline 1 & 12,530 & 0 & 8.77 & $\underline{0}$ & 8.77 \\
\hline 2 & 5,140 & 0 & 3.60 & 0 & 3.60 \\
\hline 3 & 73,550 & 0 & 51.49 & 0 & 51.49 \\
\hline 4 & 53,046 & 0 & 37.13 & 0 & 37.13 \\
\hline 5 & 4,500 & 0 & 3.15 & $\underline{0}$ & 3.15 \\
\hline 6 & 0 & 0 & - & 0 & - \\
\hline 7 & 0 & 0 & - & 0 & - \\
\hline TOTALS & 148,766 & 0 & 104 & & 104 \\
\hline \multicolumn{6}{|c|}{ Renewable Energy Projects } \\
\hline 8 & 410 & 0 & 0.29 & 0 & 0.29 \\
\hline 9 & 191,072 & 0 & 133.75 & 0 & 133.75 \\
\hline TOTALS & 191,482 & 0 & 134 & - & 134 \\
\hline
\end{tabular}




\subsection{Action Plan for Implementation of ECMs}

The goal of providing technical assistance to agencies is to provide them with sufficient information so they can make informed decisions regarding implementation of the proposed measures.

\subsection{Priorities and Next Steps}

The FAA has indicated it will incorporate the seven ECMs into the final design and operating specifications. FAA representatives also indicated that they may consider other recommended measures, such as additional renewable energy projects, but a separate funding source would have to be identified and assistance would be required to obtain the funding.

The design review team also recommended that operating staff at the new building become familiar with the information contained in the documents listed below so the installed equipment can be properly maintained to maximize the useful life of energy related equipment.

$\checkmark$ FEMP Retro-commissioning after completion of the building www.eere.energy.gov/femp/pdfs/om retrocx.pdf

$\checkmark$ FEMP Best Practices Operations and Maintenance www.eere.energy.gov/femp/operations maintenance/om bpguide.ht $\underline{\mathrm{ml}}$

\subsection{Funding Assistance Available}

The ECMs selected are expected to be included in the overall cost to construct and operate the base building and the control tower. Thus, funding assistance is not required for this site, except for the renewable energy projects. The FAA is encouraged to contact its utility representative from Idaho Power regarding potential additional incentives for solar installations and other energy conservation measures. 


\subsection{Assessment Team Members and Site Team}

Mr. Jim Arends, PE, CEM, of Redhorse completed the technical review of the design and operating specifications for the site. Mr. Arends was assisted by Mr. Brent Higginbotham, PE, of Redhorse during the site visit. Mr. Nick Mirhaydari, Mr. Robert Smith and Mr. Mark Brandewie of FAA also participated in the site visit. Ms. Amanda Sahl, DOE Headquarters, also participated in the site visit. Mr. William Sandusky of PNNL was responsible for technical review of this report. 


\subsection{References}

Department of Energy (DOE). 1998. FEMP Federal Technology Alert Ultrasonic Humidifiers, DOE/EE-0180.

http://www1.eere.energy.gov/femp/pdfs/FTA UltraHumid.pdf

National Resources of Canada (NRC). 2010. RETScreen ${ }^{\circledR}$ Clean Energy Project Analysis Software from RETScreen International. http://www.retscreen.net/ang/t software.php.

E.H. Pechan \& Associates (Pechan). September 2008. The Emissions \& Generation Resource Integrated Database for 2007 (eGRID 2007). Report Number 08.09.006/9011.239. Springfield, Virginia. 


\section{APPENDIX A}

eQUEST Modeling Results and Spreadsheet Calculations 



\section{Appendix A: eQUEST Modeling Results and Spreadsheet Calculations}

Energy simulations developed for the annual energy savings estimates were modeled using eQUEST version 3.61. The schematic design model was used to develop the building footprint and input basic building systems. Basic model inputs include: 24 hours a day operation for 7 days a week, one variable volume air handler serving the majority of the base building, with the balance of the building served by constant volume air handling systems. The control tower provides air traffic controller occupied space on the $8^{\text {th }}$ floor.

\section{Baseline eQUEST Model Results}

\begin{tabular}{|c|c|c|c|c|c|c|c|c|c|c|c|c|c|}
\hline \multicolumn{14}{|c|}{ eQUEST Model Results Baseline Use } \\
\hline \multicolumn{14}{|c|}{ Electric Consumption (kWh x000) } \\
\hline & Jan & Feb & Mar & Apr & May & Jun & Jul & Aug & Sep & Oct & Nov & Dec & Total \\
\hline Space Cool & 0.85 & 0.77 & 0.85 & 1.94 & 4.71 & 7.52 & 14.93 & 10.65 & 6.44 & 2.51 & 0.83 & 0.85 & 52.84 \\
\hline Heat Reject. & 0 & 0 & 0 & 0 & 0 & 0 & 0 & 0 & 0 & 0 & 0 & 0 & 0 \\
\hline Refrigeration & 0 & 0 & 0 & 0 & 0 & 0 & 0 & 0 & 0 & 0 & 0 & 0 & 0 \\
\hline Space Heat & 12.23 & 5.96 & 4.31 & 1.89 & 1.36 & 0.86 & 0.85 & 0.61 & 0.68 & 1.98 & 5.02 & 11.77 & 47.52 \\
\hline HP Supp. & 0 & 0 & 0 & 0 & 0 & 0 & 0 & 0 & 0 & 0 & 0 & 0 & 0 \\
\hline Hot Water & 0.38 & 0.37 & 0.43 & 0.42 & 0.36 & 0.36 & 0.33 & 0.31 & 0.3 & 0.32 & 0.31 & 0.39 & 4.27 \\
\hline Vent. Fans & 6.28 & 6.02 & 6.93 & 7.09 & 6.96 & 7.11 & 6.76 & 6.98 & 7.08 & 7.16 & 6.37 & 6.57 & 81.3 \\
\hline Pumps \& Aux. & 6.1 & 6.99 & 9.76 & 10.32 & 5.66 & 5.44 & 3.48 & 3.68 & 4.62 & 6.65 & 6.83 & 7.27 & 76.8 \\
\hline Ext. Usage & 0 & 0 & 0 & 0 & 0 & 0 & 0 & 0 & 0 & 0 & 0 & 0 & 0 \\
\hline Misc. Equip. & 34.49 & 32.24 & 36.85 & 36.45 & 34.49 & 36.45 & 36.78 & 35.69 & 35.29 & 35.62 & 32.96 & 36.81 & 424.11 \\
\hline Task Lights & 0 & 0 & 0 & 0 & 0 & 0 & 0 & 0 & 0 & 0 & 0 & 0 & 0 \\
\hline Area Lights & 5.79 & 5.48 & 6.33 & 6.3 & 5.79 & 6.3 & 6.31 & 6.06 & 6.04 & 6.05 & 5.51 & 6.32 & 72.29 \\
\hline Total & 66.12 & 57.83 & 65.45 & 64.4 & 59.33 & 64.04 & 69.43 & 63.98 & 60.45 & 60.27 & 57.83 & 69.98 & 759.12 \\
\hline
\end{tabular}

Static Pressure Reset Model Results

\begin{tabular}{|c|c|c|c|c|c|c|c|c|c|c|c|c|c|}
\hline \multicolumn{14}{|c|}{ eQUEST Model Results Static Pressure Reset } \\
\hline \multicolumn{14}{|c|}{ Electric Consumption (kWh x000) } \\
\hline & Jan & Feb & Mar & Apr & May & Jun & Jul & Aug & Sep & Oct & Nov & Dec & Total \\
\hline Space Cool & 0.85 & 0.77 & 0.85 & 1.92 & 4.63 & 7.39 & 14.71 & 10.48 & 6.34 & 2.48 & 0.83 & 0.85 & 52.1 \\
\hline Heat Reject & 0 & 0 & 0 & 0 & 0 & 0 & 0 & 0 & 0 & 0 & 0 & 0 & 0 \\
\hline Refrigeratio & 0 & 0 & 0 & 0 & 0 & 0 & 0 & 0 & 0 & 0 & 0 & 0 & 0 \\
\hline Space Heat & 12.44 & 6.03 & 4.32 & 1.9 & 1.36 & 0.88 & 0.87 & 0.63 & 0.68 & 1.99 & 5.06 & 11.97 & 48.14 \\
\hline HP Supp. & 0 & 0 & 0 & 0 & 0 & 0 & 0 & 0 & 0 & 0 & 0 & 0 & 0 \\
\hline Hot Water & 0.38 & 0.37 & 0.43 & 0.42 & 0.36 & 0.36 & 0.33 & 0.31 & 0.3 & 0.32 & 0.31 & 0.39 & 4.27 \\
\hline Vent. Fans & 5.37 & 5.24 & 6.08 & 6.31 & 6.14 & 6.35 & 5.94 & 6.19 & 6.33 & 6.36 & 5.54 & 5.68 & 71.54 \\
\hline Pumps \& Au & 5.85 & 6.69 & 9.39 & 9.95 & 5.48 & 5.33 & 3.42 & 3.6 & 4.51 & 6.42 & 6.54 & 6.99 & 74.16 \\
\hline Ext. Usage & 0 & 0 & 0 & 0 & 0 & 0 & 0 & 0 & 0 & 0 & 0 & 0 & 0 \\
\hline Misc. Equip. & 34.49 & 32.24 & 36.85 & 36.45 & 34.49 & 36.45 & 36.78 & 35.69 & 35.29 & 35.62 & 32.96 & 36.81 & 424.11 \\
\hline Task Lights & 0 & 0 & 0 & 0 & 0 & 0 & 0 & 0 & 0 & 0 & 0 & 0 & 0 \\
\hline Area Lights & 5.79 & 5.48 & 6.33 & 6.3 & 5.79 & 6.3 & 6.31 & 6.06 & 6.04 & 6.05 & 5.51 & 6.32 & 72.29 \\
\hline Total & 65.18 & 56.82 & 64.24 & 63.24 & 58.25 & 63.07 & 68.36 & 62.95 & 59.49 & 59.23 & 56.75 & 69 & 746.59 \\
\hline
\end{tabular}




\section{$\underline{\text { Demand Control }\left(\mathrm{CO}_{2}\right) \text { Ventilation Model Results }}$}

\begin{tabular}{|c|c|c|c|c|c|c|c|c|c|c|c|c|c|}
\hline \multicolumn{14}{|c|}{ eQUEST Model Results DCV CO2 } \\
\hline \multicolumn{14}{|c|}{ Electric Consumption (kWh x000) } \\
\hline & Jan & Feb & Mar & Apr & May & Jun & Jul & Aug & Sep & Oct & Nov & Dec & Total \\
\hline Space Cool & 1.8 & 1.55 & 1.64 & 2.69 & 5.4 & 7.78 & 14.86 & 10.93 & 6.93 & 3.36 & 1.8 & 1.62 & 60.36 \\
\hline Heat Reject. & 0 & 0 & 0 & 0 & 0 & 0 & 0 & 0 & 0 & 0 & 0 & 0 & 0 \\
\hline Refrigeration & 0 & 0 & 0 & 0 & 0 & 0 & 0 & 0 & 0 & 0 & 0 & 0 & 0 \\
\hline Space Heat & 11.44 & 5.68 & 4.09 & 1.73 & 1.24 & 0.83 & 0.84 & 0.59 & 0.61 & 1.81 & 4.73 & 10.98 & 44.59 \\
\hline HP Supp. & 0 & 0 & 0 & 0 & 0 & 0 & 0 & 0 & 0 & 0 & 0 & 0 & 0 \\
\hline Hot Water & 0.38 & 0.37 & 0.43 & 0.42 & 0.36 & 0.36 & 0.33 & 0.31 & 0.3 & 0.32 & 0.31 & 0.39 & 4.27 \\
\hline Vent. Fans & 6.29 & 6.03 & 6.93 & 7.09 & 6.97 & 7.1 & 6.75 & 6.98 & 7.08 & 7.17 & 6.38 & 6.57 & 81.33 \\
\hline Pumps \& Aux. & 5.02 & 5.93 & 8.91 & 8.98 & 4.75 & 5.05 & 3.06 & 3.22 & 4.09 & 6 & 5.83 & 6.2 & 67.03 \\
\hline Ext. Usage & 0 & 0 & 0 & 0 & 0 & 0 & 0 & 0 & 0 & 0 & 0 & 0 & 0 \\
\hline Misc. Equip. & 34.49 & 32.24 & 36.85 & 36.45 & 34.49 & 36.45 & 36.78 & 35.69 & 35.29 & 35.62 & 32.96 & 36.81 & 424.11 \\
\hline Task Lights & 0 & 0 & 0 & 0 & 0 & 0 & 0 & 0 & 0 & 0 & 0 & 0 & 0 \\
\hline Area Lights & 5.79 & 5.48 & 6.33 & 6.3 & 5.79 & 6.3 & 6.31 & 6.06 & 6.04 & 6.05 & 5.51 & 6.32 & 72.29 \\
\hline Total & 65.2 & 57.27 & 65.19 & 63.65 & 58.99 & 63.87 & 68.93 & 63.78 & 60.35 & 60.32 & 57.53 & 68.9 & 753.98 \\
\hline
\end{tabular}

\section{Lighting and HVAC Occupancy Sensor Model Results}

eQUEST Model Results Lighting and HVAC Occupancy Sensors Electric Consumption ( $\mathrm{kWh} \times 000$ )

\begin{tabular}{|c|c|c|c|c|c|c|c|c|c|c|c|c|c|}
\hline & Jan & Feb & Mar & Apr & May & Jun & Jul & Aug & Sep & Oct & Nov & Dec & Total \\
\hline Space Cool & 0.84 & 0.76 & 0.84 & 1.89 & 4.61 & 7.35 & 14.6 & 10.42 & 6.29 & 2.46 & 0.82 & 0.84 & 51.71 \\
\hline Heat Reject. & 0 & 0 & 0 & 0 & 0 & 0 & 0 & 0 & 0 & 0 & 0 & 0 & 0 \\
\hline Refrigeration & 0 & 0 & 0 & 0 & 0 & 0 & 0 & 0 & 0 & 0 & 0 & 0 & 0 \\
\hline Space Heat & 12.42 & 6.03 & 4.36 & 1.91 & 1.35 & 0.83 & 0.79 & 0.58 & 0.67 & 1.99 & 5.07 & 11.95 & 47.96 \\
\hline HP Supp. & 0 & 0 & 0 & 0 & 0 & 0 & 0 & 0 & 0 & 0 & 0 & 0 & 0 \\
\hline Hot Water & 0.38 & 0.37 & 0.43 & 0.42 & 0.36 & 0.36 & 0.33 & 0.31 & 0.3 & 0.32 & 0.31 & 0.39 & 4.27 \\
\hline Vent. Fans & 6.19 & 5.93 & 6.81 & 6.95 & 6.83 & 6.97 & 6.65 & 6.85 & 6.93 & 7.02 & 6.27 & 6.46 & 79.86 \\
\hline Pumps \& Aux. & 1.5 & 1.35 & 1.5 & 1.45 & 1.5 & 1.45 & 1.5 & 1.5 & 1.45 & 1.5 & 1.45 & 1.5 & 17.62 \\
\hline Ext. Usage & 0 & 0 & 0 & 0 & 0 & 0 & 0 & 0 & 0 & 0 & 0 & 0 & 0 \\
\hline Misc. Equip. & 34.49 & 32.24 & 36.85 & 36.45 & 34.49 & 36.45 & 36.78 & 35.69 & 35.29 & 35.62 & 32.96 & 36.81 & 424.11 \\
\hline Task Lights & 0 & 0 & 0 & 0 & 0 & 0 & 0 & 0 & 0 & 0 & 0 & 0 & 0 \\
\hline Area Lights & 4.81 & 4.55 & 5.26 & 5.24 & 4.81 & 5.24 & 5.24 & 5.04 & 5.02 & 5.02 & 4.58 & 5.25 & 60.05 \\
\hline Total & 60.62 & 51.22 & 56.04 & 54.31 & 53.95 & 58.64 & 65.89 & 60.38 & 55.95 & 53.93 & 51.46 & 63.19 & 685.57 \\
\hline
\end{tabular}

\section{Ultrasonic Humidifiers Model Results}

\begin{tabular}{|c|c|c|c|c|c|c|c|c|c|c|c|c|c|}
\hline \multicolumn{14}{|c|}{ eQUEST Model Results Ultrasonic Humidifiers } \\
\hline \multicolumn{14}{|c|}{ Electric Consumption (kWh x000) } \\
\hline & Jan & Feb & Mar & Apr & May & Jun & Jul & Aug & Sep & Oct & Nov & Dec & Total \\
\hline Space Cool & 0.85 & 0.77 & 0.85 & 1.94 & 4.71 & 7.52 & 14.93 & 10.65 & 6.44 & 2.51 & 0.83 & 0.85 & 52.84 \\
\hline Heat Reject. & 0 & 0 & 0 & 0 & 0 & 0 & 0 & 0 & 0 & 0 & 0 & 0 & 0 \\
\hline Refrigeration & 0 & 0 & 0 & 0 & 0 & 0 & 0 & 0 & 0 & 0 & 0 & 0 & 0 \\
\hline Space Heat & 12.22 & 5.96 & 4.31 & 1.89 & 1.36 & 0.86 & 0.85 & 0.61 & 0.68 & 1.98 & 5.01 & 11.77 & 47.51 \\
\hline HP Supp. & 0 & 0 & 0 & 0 & 0 & 0 & 0 & 0 & 0 & 0 & 0 & 0 & 0 \\
\hline Hot Water & 0.38 & 0.37 & 0.43 & 0.42 & 0.36 & 0.36 & 0.33 & 0.31 & 0.3 & 0.32 & 0.31 & 0.39 & 4.27 \\
\hline Vent. Fans & 6.28 & 6.02 & 6.93 & 7.09 & 6.96 & 7.11 & 6.76 & 6.98 & 7.08 & 7.16 & 6.37 & 6.57 & 81.3 \\
\hline Pumps \& Aux. & 1.52 & 1.37 & 1.52 & 1.47 & 1.52 & 1.47 & 1.52 & 1.52 & 1.47 & 1.52 & 1.47 & 1.52 & 17.87 \\
\hline Ext. Usage & 0 & 0 & 0 & 0 & 0 & 0 & 0 & 0 & 0 & 0 & 0 & 0 & 0 \\
\hline Misc. Equip. & 34.49 & 32.24 & 36.85 & 36.45 & 34.49 & 36.45 & 36.78 & 35.69 & 35.29 & 35.62 & 32.96 & 36.81 & 424.11 \\
\hline Task Lights & 0 & 0 & 0 & 0 & 0 & 0 & 0 & 0 & 0 & 0 & 0 & 0 & 0 \\
\hline Area Lights & 5.79 & 5.48 & 6.33 & 6.3 & 5.79 & 6.3 & 6.31 & 6.06 & 6.04 & 6.05 & 5.51 & 6.32 & 72.29 \\
\hline Total & 61.53 & 52.21 & 57.21 & 55.55 & 55.19 & 60.07 & 67.47 & 61.82 & 57.29 & 55.14 & 52.47 & 64.22 & 700.18 \\
\hline
\end{tabular}




\section{No Touch Sink Faucets Spreadsheet Calculation Results}

U.S. Department of Energy - Energy Efficiency and Renewable Energy

Federal Energy Management Program

Energy Cost Calculator for Faucets and Showerheads

http://www1.eere.energy.gov/femp/technologies/printable versions/eep faucets shower heads calc.html\#output

Vary utility cost, hours of operation, and /or efficiency level.

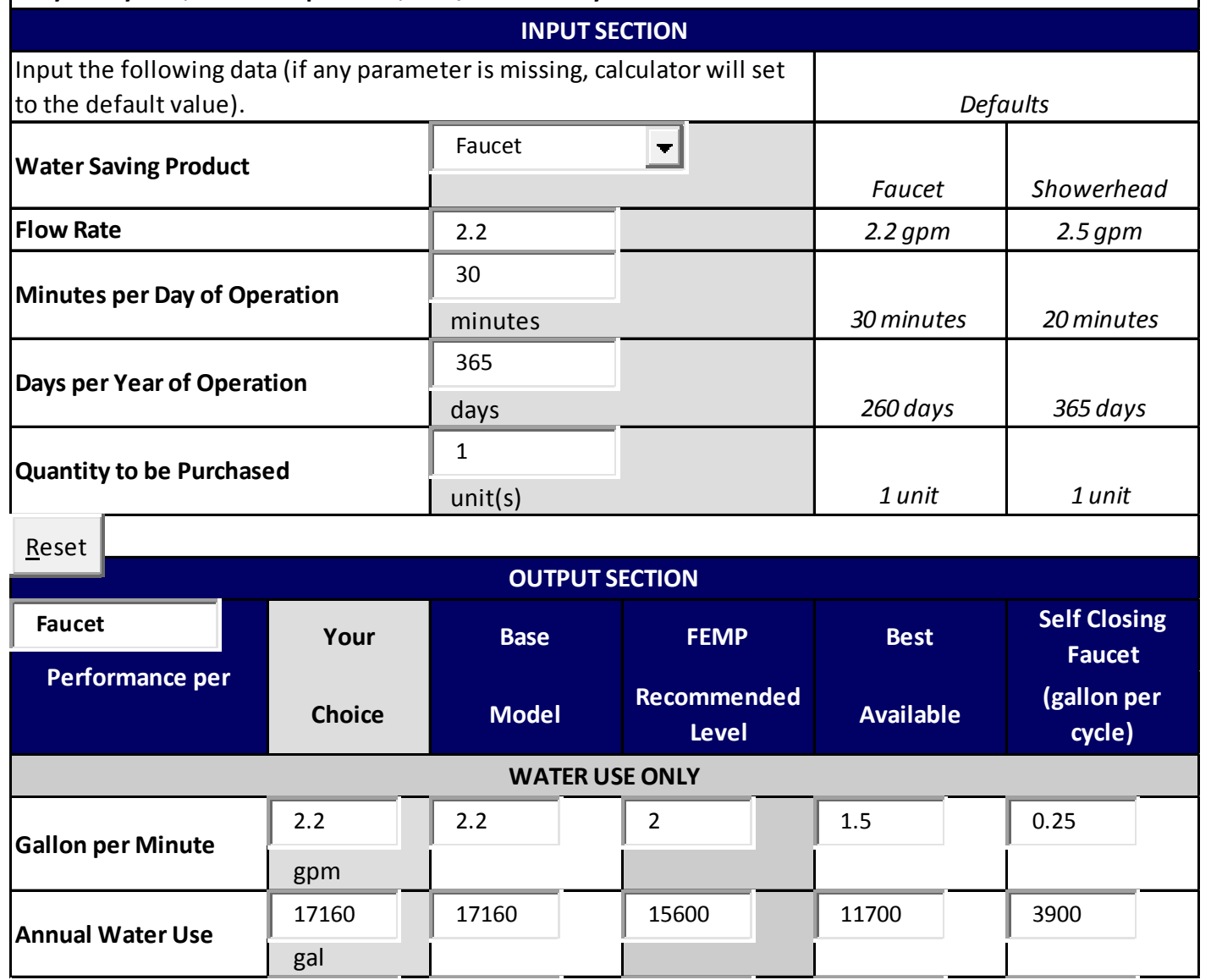




\section{No Touch Urinals Spreadsheet Calculation Results}

U.S. Department of Energy - Energy Efficiency and Renewable Energy

Federal Energy Management Program

Energy Cost Calculator for Urinals

http://www1.eere.energy.gov/femp/technologies/printable versi ons/eep toilets urinals calc.html\#output

Vary water cost, frequency of operation, and /or efficiency level.

\section{INPUT SECTION}

This calculator assumes that early replacement of a urinal or toilet will take place with 10 years of life remaining for existing fixture.

\begin{tabular}{|c|c|c|c|c|}
\hline \multicolumn{3}{|c|}{$\begin{array}{l}\text { Input the following data (if any parameter is } \\
\text { missing, calculator will set to default value). }\end{array}$} & \multirow{2}{*}{\multicolumn{2}{|c|}{ Defaults }} \\
\hline Water Saving Product & Urinal & $\nabla$ & & \\
\hline \multirow{2}{*}{ Gallons per Flush } & \multicolumn{2}{|l|}{0.5} & \multirow{2}{*}{\multicolumn{2}{|c|}{$1.0 \mathrm{gpf}$}} \\
\hline & \multicolumn{2}{|l|}{ gpf } & & \\
\hline Quantity to be Purchased & \multicolumn{2}{|l|}{1} & \multicolumn{2}{|c|}{1} \\
\hline Flushes per Day & 30 & & \multicolumn{2}{|c|}{30 flushes } \\
\hline Days per Year & \multicolumn{2}{|l|}{365} & \multicolumn{2}{|c|}{260 days } \\
\hline & \multicolumn{2}{|c|}{ OUTPUT SECTION } & \\
\hline Performance per & Your & Typical & \multirow{2}{*}{$\begin{array}{l}\text { Recommen } \\
\text { ded Level } \\
\text { (New Unit) }\end{array}$} & Best \\
\hline urinal & Choice & $\begin{array}{c}\text { Existing } \\
\text { Unit }\end{array}$ & & Available \\
\hline \multirow{2}{*}{ Gallon per Flush } & 0.5 & 3 & 1 & 0 \\
\hline & gpf & & & \\
\hline \multirow{2}{*}{ Annual Water Use } & 5475 & 32850 & 10950 & 0 \\
\hline & gal & & & \\
\hline
\end{tabular}




\section{No Touch Toilets Spreadsheet Calculation Results}

\begin{tabular}{|c|c|c|c|c|}
\hline Toilet Water Use & & & & \\
\hline Number of toilets & & 6 & & \\
\hline Number of people & & 25 & & \\
\hline Flushes/person/day & & 2 & \multicolumn{2}{|c|}{ Use 5 for residential, 2 for office use } \\
\hline Days used per week & & 7 & \multicolumn{2}{|c|}{7 for residential, 5 for office } \\
\hline Existing single flush volume (US gal) & & 1.6 & \multicolumn{2}{|c|}{ Generally $5,3.5$ or 1.6 gal/flush } \\
\hline \multicolumn{5}{|l|}{ Water Consumption Calculations } \\
\hline & & $\begin{array}{l}\text { Single } \\
\text { Flush } \\
\text { Toilets }\end{array}$ & $\begin{array}{c}\text { No } \\
\text { Touch } \\
\text { Toilets }\end{array}$ & \\
\hline Flush Volume & gal & 1.6 & 1.28 & \\
\hline Flushes per day & $\#$ & 50 & 50 & \\
\hline Water use per day & gal & 80 & 64 & \\
\hline Water use per toilet per day & gal & 13.3 & 10.7 & \\
\hline Water use per year & gal & 29120 & 23296 & \\
\hline Daily water use reduction & & & 16.0 & gal/day \\
\hline Annual Water use reduction & & & 5824 & gal/yr \\
\hline
\end{tabular}




\section{Solar Hot Water Spreadsheet Calculation Results}

\section{RETScreen Tool}

Technology

Load characteristics

Load type

Number of units

Occupancy rate

Daily hot water use - estimated

Daily hot water use

Temperature

Operating days per week

Supply temperature method

Water temperature - minimum

Water temperature - maximum

Heating

Resource assessment

Solar tracking mode

Slope

Azimuth

Solar water heater

Type

Manufacturer

Model

Gross area per solar collector

Aperture area per solar collector

$\mathrm{Fr}$ (tau alpha) coefficient

Wind correction for $\mathrm{Fr}$ (tau alpha)

Fr UL coefficient

Wind correction for Fr UL

Number of collectors

Solar collector area

Cost

Capacity

Miscellaneous losses

Balance of system \& miscellaneous Storage

Storage capacity / solar collector area

Storage capacity

Heat exchanger

Heat exchanger efficiency

Miscellaneous losses

Pump power / solar collector area

Electricity rate

\section{Summary}

Electricity - pump

Heating delivered

Solar fraction

Heating system

Fuel type

Seasonal efficiency

Fuel consumption - annual
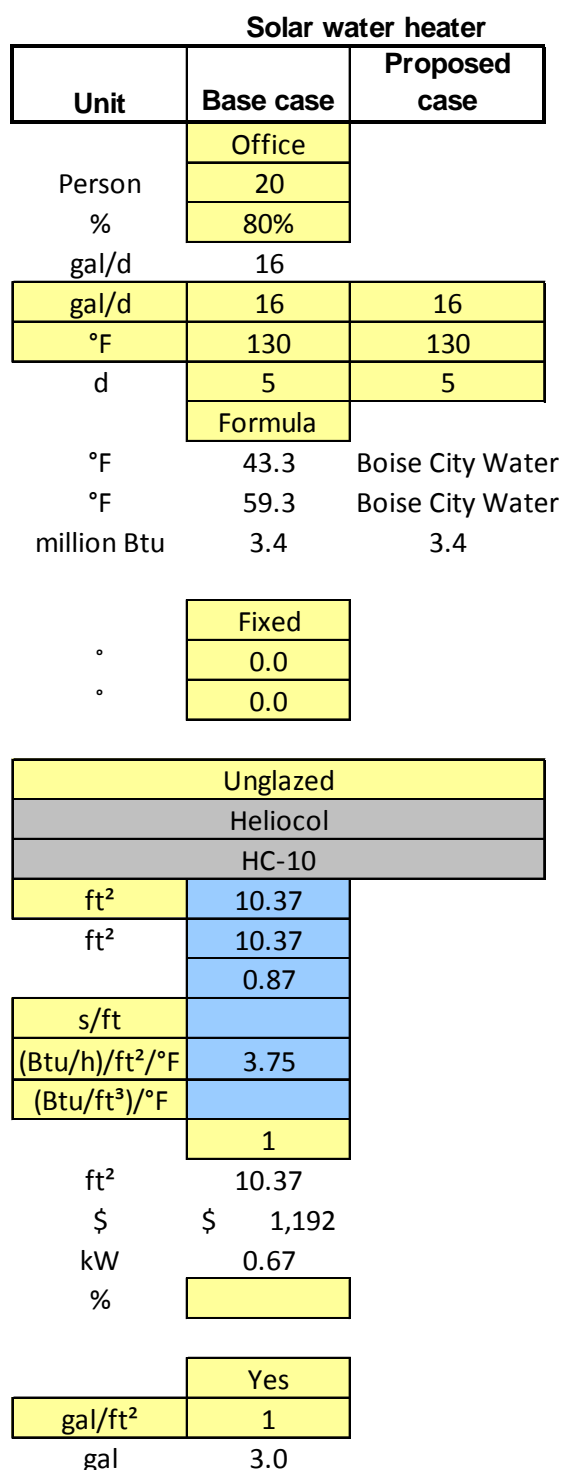

\begin{tabular}{|c|c|}
\cline { 2 - 2 } yes/no & Yes \\
\cline { 2 - 2 }$\%$ & $60.0 \%$ \\
\cline { 2 - 2 }$\%$ & $10.0 \%$ \\
\hline $\mathrm{W} / \mathrm{ft}^{2}$ & 0.10 \\
\hline \multirow{2}{*}{$\$ / \mathrm{kWh}$} & 0.103 \\
\hline
\end{tabular}

\begin{tabular}{|c|c|c|c|}
\hline $\mathrm{MWh}$ & 0.0 & & \\
\hline million Btu & 2.0 & & \\
\hline \multirow[t]{4}{*}{$\%$} & $60 \%$ & & \\
\hline & Base case & $\begin{array}{c}\text { Proposed } \\
\text { case }\end{array}$ & $\begin{array}{c}\text { Proposed } \\
\text { Savings }\end{array}$ \\
\hline & $\begin{array}{c}\text { Electrical } \\
\text { Costs kWh }\end{array}$ & $\begin{array}{c}\text { Electrical } \\
\text { Costs kWh }\end{array}$ & $\begin{array}{l}\text { Electrical } \\
\text { Costs kWh }\end{array}$ \\
\hline & $95 \%$ & $95 \%$ & \\
\hline therm & 996.2 & 586.0 & 410.2 \\
\hline
\end{tabular}

A-6 


\section{Solar Power Generation Online Calculation Results}

\begin{tabular}{|c|c|c|c|c|}
\hline \multicolumn{5}{|c|}{ PV Watts AC Energy \& Cost Savings } \\
\hline \multicolumn{2}{|c|}{ Station Identification } & \multicolumn{3}{|c|}{ Results } \\
\hline City: & Boise & Month & Solar Radiation & AC Energy \\
\hline State: & Idaho & & $\left(\mathrm{kWh} / \mathrm{m}^{2} /\right.$ day $)$ & $(\mathrm{kWh})$ \\
\hline Latitude: & $43.57^{\circ} \mathrm{N}$ & 1 & 2.88 & 9,660 \\
\hline Longitude: & $116.22^{\circ} \mathrm{W}$ & 2 & 4.16 & 12,574 \\
\hline Elevation: & $874 \mathrm{~m}$ & 3 & 4.93 & 16,204 \\
\hline \multicolumn{2}{|c|}{ PV System Specifications } & 4 & 5.77 & 17,737 \\
\hline DC Rating: & $140.0 \mathrm{~kW}$ & 5 & 6.12 & 18,969 \\
\hline DC to AC Derate Factor: & 0.77 & 6 & 6.47 & 18,928 \\
\hline AC Rating: & $107.8 \mathrm{~kW}$ & 7 & 7.05 & 20,367 \\
\hline Array Type: & Fixed Tilt & 8 & 6.93 & 20,539 \\
\hline Array Tilt: & $43.6^{\circ}$ & 9 & 6.40 & 18,759 \\
\hline \multirow[t]{3}{*}{ Array Azimuth: } & $180.0^{\circ}$ & 10 & 5.30 & 16,843 \\
\hline & & 11 & 3.48 & 10,971 \\
\hline & & 12 & 2.80 & 9,521 \\
\hline & & & & 191,072 \\
\hline
\end{tabular}


A-8 


\section{APPENDIX B}

\section{PHOTOGRAPHS}





\section{Appendix B: Photographs}

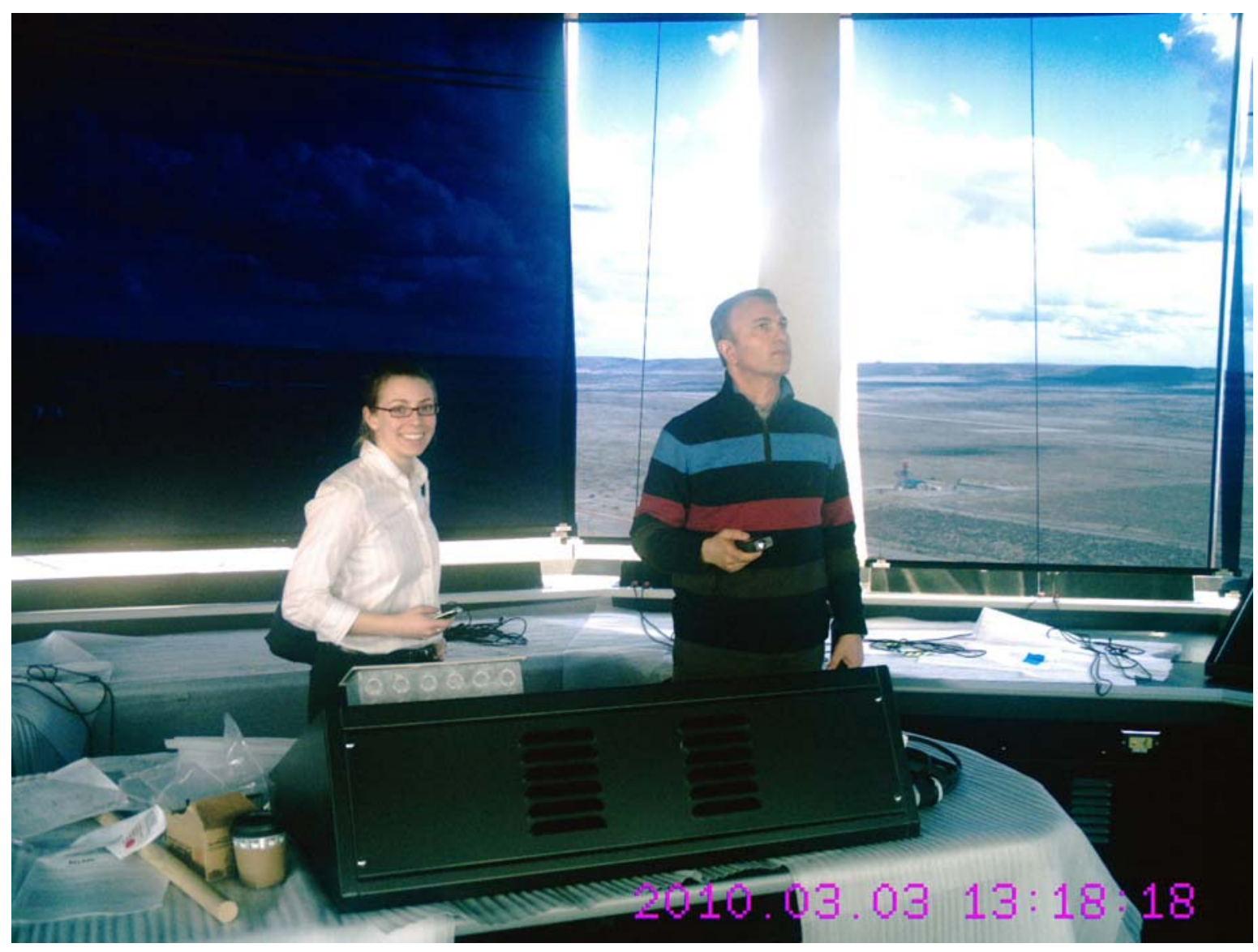

Photo 1. Boise FAA Control Tower site visit: Amanda Sahl, DOE and Nick Mirhaydari, FAA 


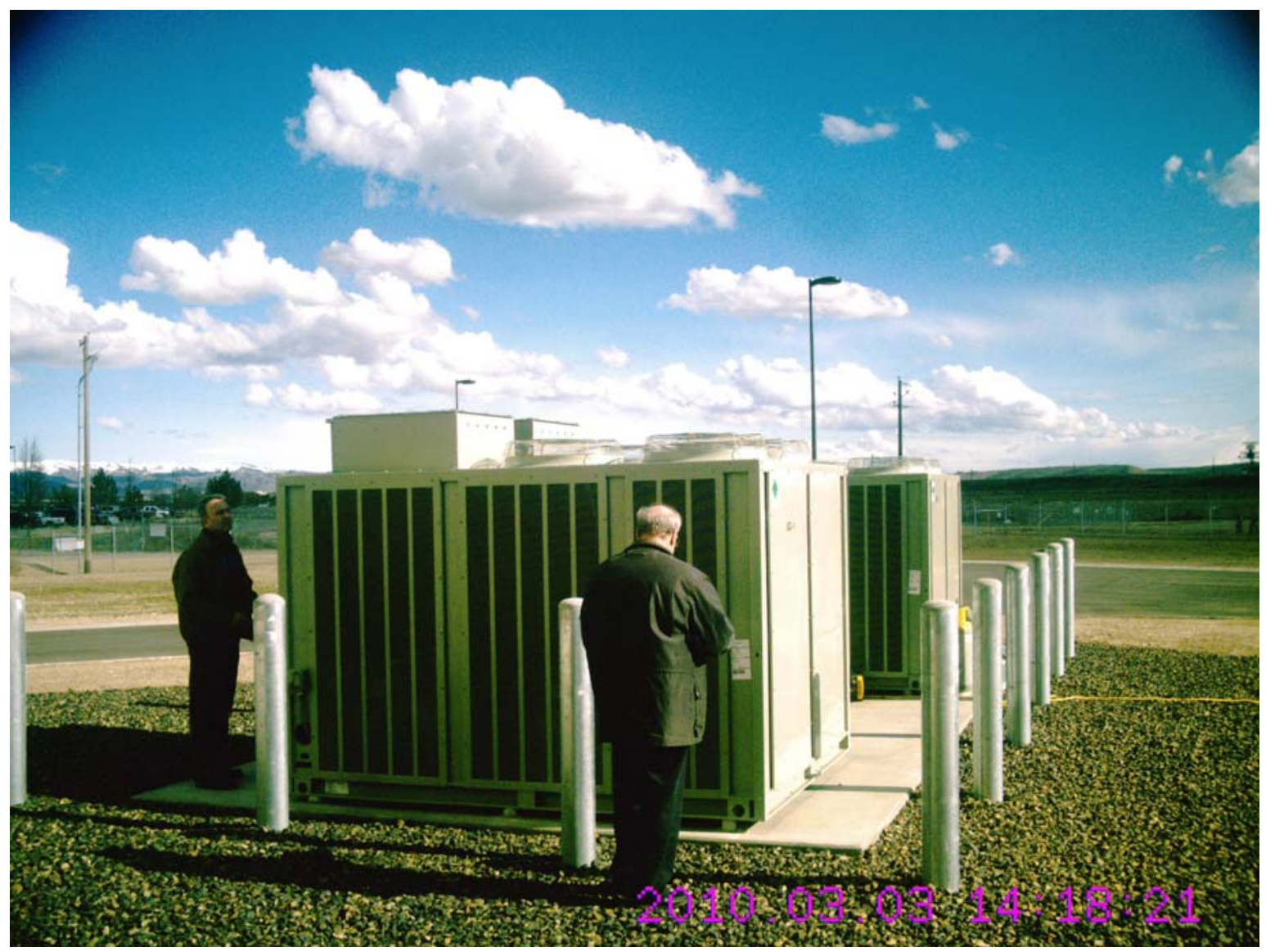

Photo 2. Boise FAA Control Tower and Base Building Chillers: Nick Mirhaydari, FAA and Brent Higginbotham, Redhorse 


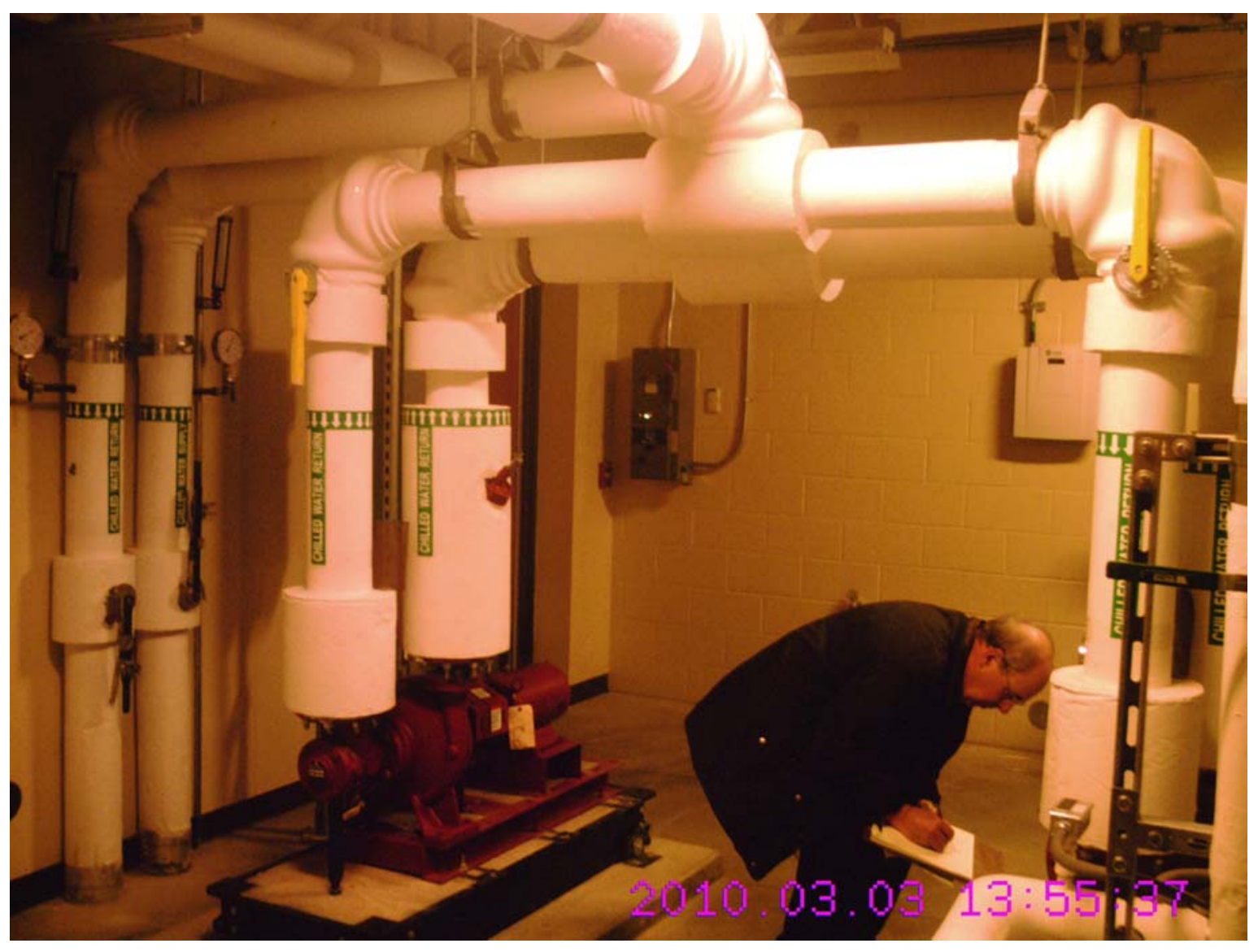

Photo 3. Boise FAA Control Tower and Base Building Chilled Water Pumps; Brent Higginbotham, Redhorse 


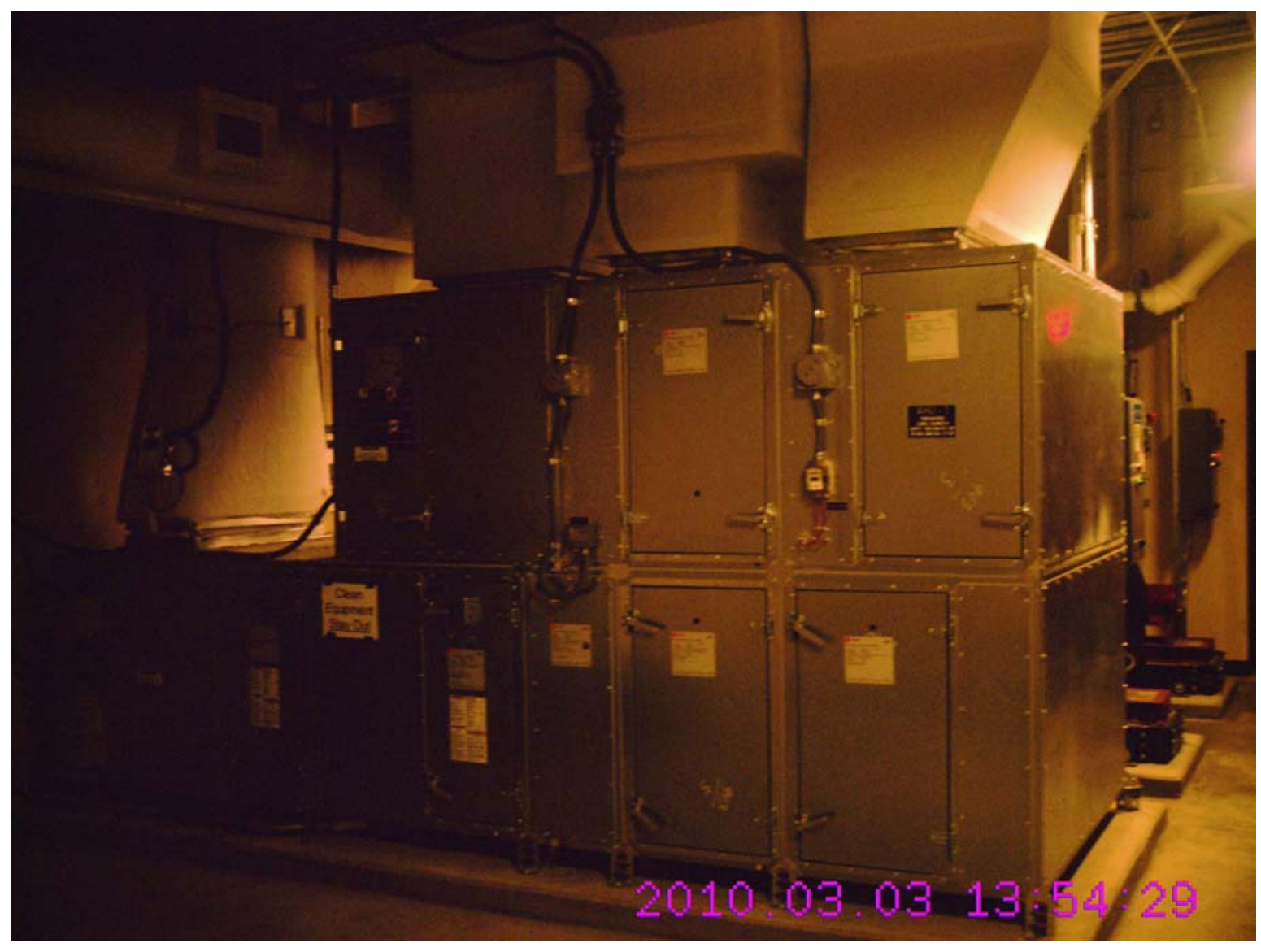

Photo 4. Boise FAA Base Building: Air Handling Unit 